\title{
Obituary
}

\section{Peter J. Golas \\ Professor of History, University of Denver, Colorado}

\section{(1937-2019)}

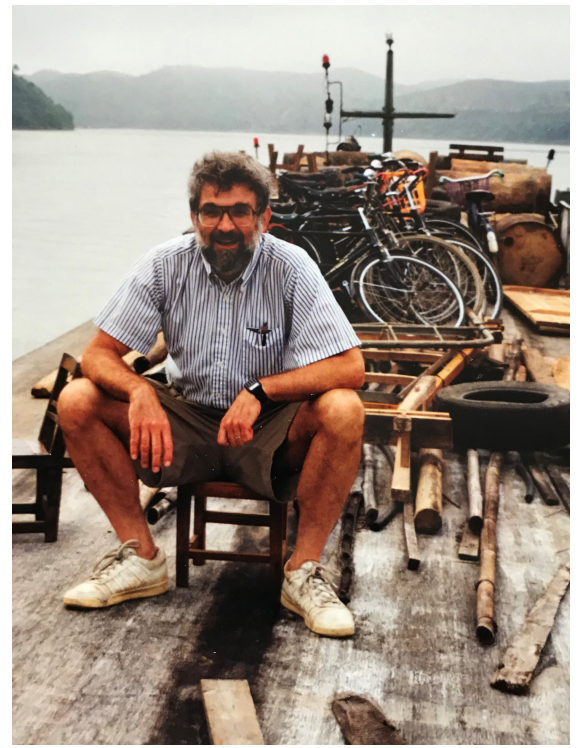

Peter somewhere in South China, 1994

I was very deeply saddened to learn that Peter J. Golas (Ge Pingde 葛平德) had passed away on 21 December 2019 in his treasured La Jolla, California. We first met in 1986, and owing to our common scholarly interests, a long friendship followed.

Peter was born on 24 April 1937 in Paterson, NJ, the son of Stella Golas and Peter Golas. He is survived by his wife, Jutta, his daughter Katherine (Maynard) and his son Philip.

After having obtained his B.A. in History and Philosophy at Fordham University in 1958 and his M.A. in History at Stanford University in 1964, Peter went to Harvard, where, in 1972, he submitted his Ph.D. thesis in History and Far Eastern Languages on the wine monopoly of the Song 
period. In 1967, still in the midst of his doctoral studies, he moved to Japan to serve as Lecturer in English at Sangyo University in Kyoto.

It was also in 1967 that he married Jutta S. Golas, who was from Germany. They had met in 1959 during Peter's stint in the US Air Force, when he was stationed there. The wedding took place in Hong Kong, and subsequently they moved to Japan, where they lived for the next five years. As a result of his Japan connection, Peter, along with Prof. James T. C. Liu (1919-1993) and Prof. Conrad Schirokauer (1929-2018), was entrusted with the mission to contact Japanese sinologists in Tokyo and Kyoto to coordinate their collaboration in the internationally organized "Sung Project," initiated by the Hungarian-born French sinologist Étienne Balazs (19051963). In Japan, Peter and Jutta not only met the famous sinologist Prof. Miyazaki Ichisada 宮崎市定 (1901-1995), but also established a long-lasting friendship with the renowned Song historian Prof. Shiba Yoshinobu 斯波義 信, his wife Kazuko and their three daughters, resulting in mutual visits and excursions both in Japan and the US over subsequent years. It was likewise in Kyoto that Jutta, who had completed her studies in Literature and French, fell in love with clay, becoming a potter for the next fifteen years. Later, her interests evolved into producing more free-form sculptural works. Her sculptures resemble a visual materia medica or bencao 本草 narrative that through their aesthetic helped to cultivate her husband's multifaceted world of scholarly sensitivities.

In 1973, Peter took up a post in Chinese History in the Department of History at Denver University, first as assistant professor, then in 1976 as associate professor, finally becoming a full professor in 1985. In 1996 he was honoured further as a Distinguished Scholar of the University of Denver. I should also mention that from 1993 to 1996 he served as Secretary of the International Society for the History of East Asian Science, Technology and Medicine. He eventually retired from his official university duties in October 2010 in order to have more time for research.

As evidenced by the topic of his Ph.D. thesis, one core area of Peter's research interests was the history of the Song Dynasty (960-1279), in particular its economic evolution, more specifically in relation to its agricultural development, fiscal administration and political economy, including Wang Anshi's 王安石 (1021-1086) “New Policies” (xinfa 新法). Representative examples of his work in this field include his article "Rural China in the Sung" ${ }^{1}$ and his contribution "The Sung Fiscal Administration" for the Cambridge History of China. ${ }^{2}$

\footnotetext{
${ }^{1}$ Golas (1980).

${ }^{2}$ Golas (2015a).
} 


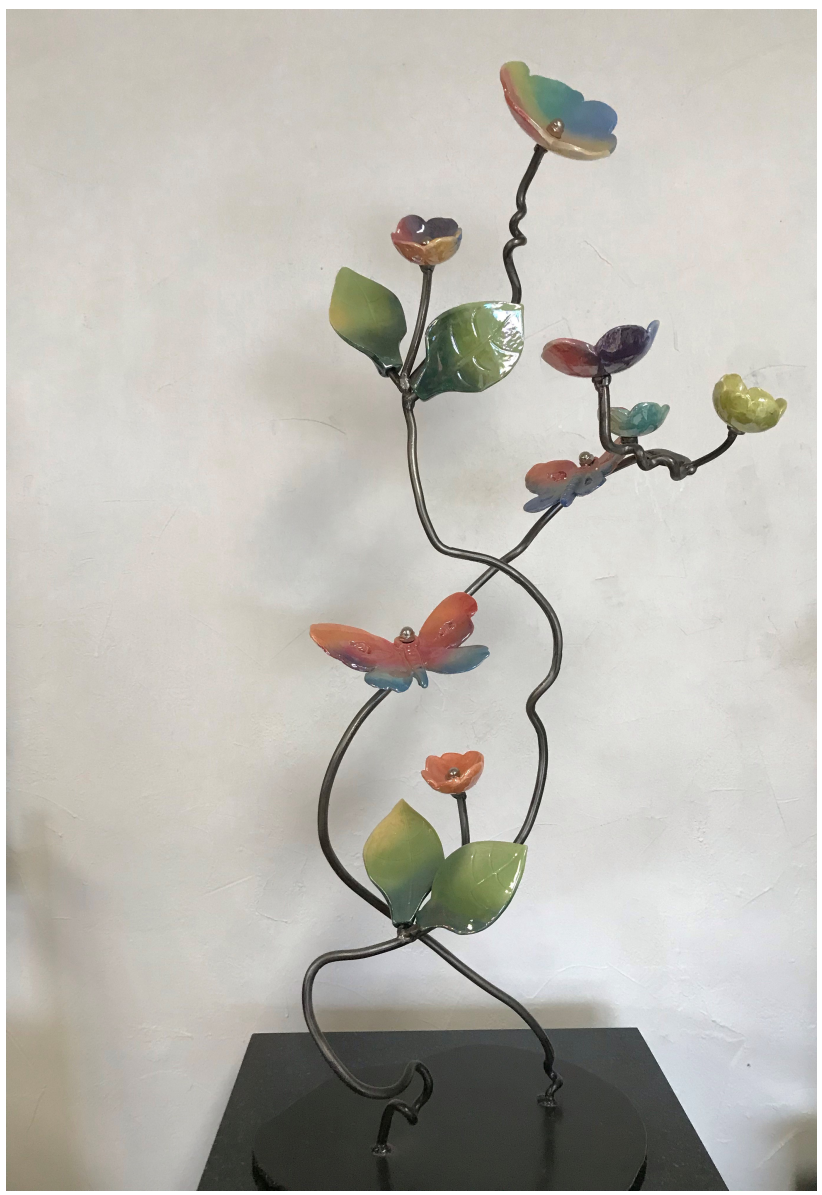

Jutta Golas, "Soft landing," July 2019

A second area in which he became deeply involved was the history of mining in China. He was already well published in this topic before this found its crowning achievement in 1999 with the publication of his monograph which constituted Volume V, Part 13: Mining of Joseph Needham's monumental Science and Civilisation in China series. ${ }^{3}$ In some respects, he was able to interweave this theme with his Song research, for instance when dealing with such topics as mining policies of the Song government or the copper precipitation process, a hydrometallurgical procedure that marked a technological breakthrough in the Song period.

${ }^{3}$ Golas (1999). 
A third research field which developed out of his former interests was the history of technical illustrations in China, culminating in his monograph Picturing Technology in China: From Earliest Time to the Nineteenth Century. ${ }^{4}$ For his next challenge, Peter was intending to write a biography of the German Jesuit Johann Adam Schall von Bell (1592-1666) and the outstanding role he played Ad maiorem Dei gloriam in the Middle Kingdom during the late Ming (1368-1644) and early Qing (1644-1911) periods. He had already collected a very substantial amount of sources and literature as well as notes on this topic, but, unfortunately, due to the onset of his illness, he had to give up this plan. Yet, though unable to pursue this project further, he was keen to bequeath his material and drafts to scholars interested in portraying Schall, a man of science, technology and God.

The strengths of Peter's research have been his systematic and analytical approaches, as represented, for instance, in his "Early Ch'ing Guilds," a contribution to G. William Skinner's The City in Late Imperial China. ${ }^{5}$ This is still a rewarding read for obtaining an initial general insight into the types and structures of guilds as they existed in China during the last imperial dynasty. Another specific feature has been his comparative approach, embodied in his studies of mining history. Some of his assessments of Chinese mining as it developed over the centuries can be highlighted here, for instance, that it was characterized by "high production, low technology," and by a large gap between those who wrote about mining and those who worked at or in the mines, or, in other words, between scholars and craftsmen. Paradoxically, while gunpowder was invented in China, it was certainly never systematically applied there in this ad-hoc production sector - in stark contrast to Europe. Substantial differences between China and Western Europe existed also in the respective developments of technical illustrations in both civilisations. All this points to differences in the development of the knowledge economy in East and West, which, in my view, have not yet been adequately addressed and discussed in debates about the "Great Divergence." A third strength of Peter was his language skills, which included Japanese, French and German as well as modern and classical Chinese, which allowed him to take the scholarship of non-English peers into due consideration.

I should also like to mention his keen intuition in the realm of conjecture. In an article in which he dealt with the history of the translation of Georgius Agricola's (1494-1555) De re metallica (1556) into Chinese, carried out with the help of Chinese assistants by Schall von Bell during the years 1638-1640, he assumed that-given the difficulty and highly

\footnotetext{
${ }^{4}$ Golas (2015b).

${ }^{5}$ Golas (1977).
} 


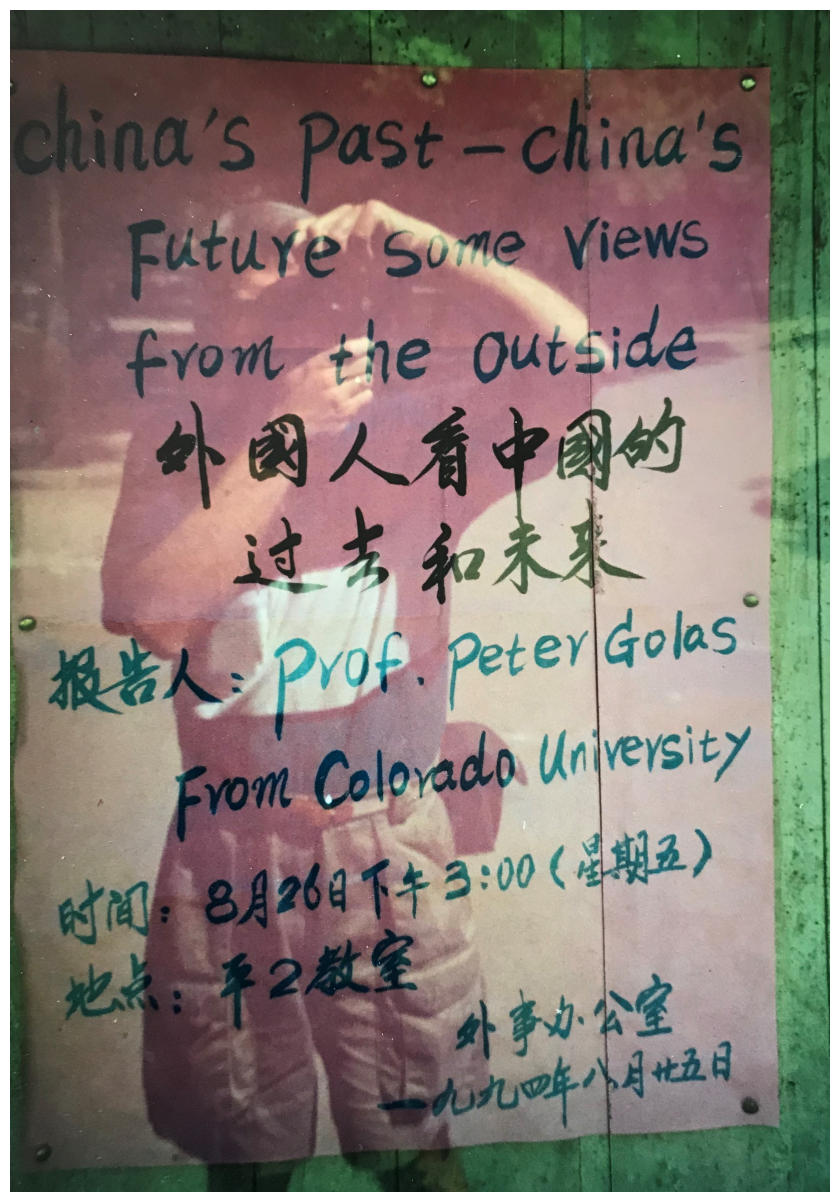

Peter's reflection in an announcement of his lecture somewhere in China, 1994

complex nature of De re metallica and the political, social and cultural circumstances of this translation project-this could only have been a selective translation. ${ }^{6}$ Today, when after more than 350 years a copy of the Chinese Agricola rendering has been discovered, this conjecture has found its full confirmation, though the story is even more complex than he had imagined, as-apart from Agricola-passages from other Renaissance metallurgists were included.

Peter worked with me together in the DAAD project "Mining and Smelting in Late Imperial China: Wu Qijun 吳其濬 (1789-1847) and the Diannan kuangchang tulüe 泪南礦廠圖略 (Illustrated Account of the Mines

${ }^{6}$ Golas (1995). 
and Smelters of Yunnan)" (2000) and was also a collaborator in our Tübingen DFG research group "Monies, Markets and Finance in East Asia (1500-1800): Local, Regional, National and International Dimensions" (2005-2012). I still recall from those days, when Peter joined the Department of Chinese Studies in Tübingen as a visiting scholar, that apart from duly organising an office for him, we also succeeded in providing an opportunity for his daily piano playing, his passion-and he made great use of it. I wish I were able to have gained his assistance again under the same arrangements for our current Tübingen DFG project "Translating Western Science, Technology and Medicine to Late Ming China: Convergences and Divergences in the Light of the Kunyu gezhi 坤輿 格致 (Investigations of the Earth's Interior; 1640) and the Taixi shuifa 泰西水 法 (Hydromethods of the Great West; 1612)," with its focus on the Kunyu gezhi, the Chinese rendering of De re metallica. Critical, analytic, systematic and comparative in outlook, Peter mastered the historian's craft, and due to his specific expertise he would have been an ideal collaborator in this transcultural research topic.

Not long ago Peter wrote to me "Hans Ulrich, we are not growing younger." He was right, but certainly his scholarly legacy will remain young.

Macau, 23 March 2020

Hans Ulrich Vogel

Chinese History and Society

Department of Chinese Studies Eberhard Karls University Tübingen 


\section{References}

Golas, Peter J. (1977), "Early Ch'ing Guilds," in G. William Skinner (ed.), The City in Late Imperial China, Stanford: Stanford University Press, pp. 555-580.

Golas, Peter J. (1980), "Rural China in the Sung," Journal of Asian Studies, 39.2: 291-325.

Golas, Peter J. (1995), "Agricola in China: A Little Problem of Translation," in Keizo Hashimoto, Catherine Jami and Lowell Skar (eds.), East Asian Science: Tradition and Beyond, Papers from the Seventh International Conference on the History of Science in East Asia, Kyoto, 2-7 August 1993, Osaka: Kansai University Press, pp. 91-96.

Golas, Peter J. (1999), Volume V, Part 13, Mining, in Joseph Needham, Science and Civilisation in China (1954-), Cambridge: Cambridge University Press.

Golas, Peter J. (2015a), "The Sung Fiscal Administration," in John W. Chaffee and Dennis Twitchett (eds.), Cambridge History of China, Volume 5: Sung China, 960-1279 AD, Part 2, Cambridge: Cambridge University Press, pp. 139-213.

Golas, Peter J. (2015b), Picturing Technology in China: From Earliest Time to the Nineteenth Century, Hong Kong: Hong Kong University Press. 